\title{
パラレルシンポジウム 9
}

\section{肝疾患と栄養}

6 月 8 日（木）第 4 会場（大会議室 A） 14:30～16:30

座長： 岩手医科大学第 1 内科鈴木 一幸

岐阜大学第 1 内科森脇 久隆

目的・主旨 : 蛋白・エネルギー栄養障害が高い頻度で慢性肝疾患とくに肝硬 変に合併し、患者のQOL や予後を規定することはよく知られている。また、こ れらに対する分岐鎖アミノ酸や分割食の効果が広く認識され、近年ではその作 用メカニズムに注目が移りつつある。一方、蛋白、エネルギー以外の栄養代謝 についても肝臓は中心臟器であり、肝疾患には様々な栄養異常が見られる。今 回のパラレルシンポジウムでは、肝疾患と栄養について、新しい話題と基礎的 メカニズムに焦点を絞った。 
PaS9-1

肝硬変患者における血清レプチン値の臨床的意義 西田勉柴田道彦佐藤智信春名能通 今野英一神田勤

(大阪府立病院消化器代謝内科)

【目的】ob遺伝子産物であるレプチン（Lep）の発 見により,これまで単にエネルギーの貯蓄脸器と考 えられていた脂肪組織が生体最大の内分泌臟器とし て認識されるようになった。肝硬変 ( LC ) 患者では レプチンを産生する脂肪組織は少なく, 体脂肪率 （\%FAT）は低下している。しかし血清 Lep 值忙上昇 していると報告もあり，その臨床的意義は明らかで ない。一般的に血清 Lep 值は BMI、\%FAT、性別、 血清 IRI 濃度に影響されるが，LCでは价㺩ン(Ins) 抵抗性や高 Ins 血症のほかに, 低栄養を認め, 血清 Lep 值におよぼす影響は明らかでない。そこで本研 究ではLCにおける血清Lep 值と病態との関連を分 析し，その臨床的意義を検討した。【対象と方法】 腎障害のない LC 54 例 [B 型 4 例、C 型 42 例、ア ルコール 5 例，その他 3 例、M/F:35/19、年齢 $66 \pm$ 8 歳了を対象とした。全例で $75 \mathrm{~g} 0 \mathrm{GTT}$ 、肝機能検查、 血清 Lep 值 (RIA 法)、BMI、\%FAT (インピーダンス法) を測 定した。【成結】(1)LC の\%FAT は女性では男性に比 し 有意に上昇 $(21.0 \pm 4.2 \%$ vs $13.0 \pm$

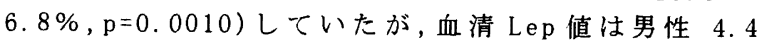
$\pm 2.6 \mathrm{ng} / \mathrm{ml}$ 、女性 $5.8 \pm 2.9 \mathrm{ng} / \mathrm{ml}$ 上性差在認めなか った $(p=0.078)$. (2) 血清 Lep 值は $75 \mathrm{~g} 0 \mathrm{GTT}$ 施行時の

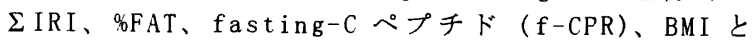
相関した。ここでこの 4 項目を説明変数として stepwise 回帰分析を行ったところ、 2 項目が有意因子として描出された（各々 $\mathrm{F}=14.376$, 15.920)。(3)血清 Lep 值と総ビリルビン值, 血清ア ルブミン濃度,HPT, Child Pugh score で評価した 肝機能との間には相関を認めなかった。【考案】ア ルコール性肝硬変患者では血清 L e p 值は上昇し, 健 常人と同様に女性で有意に高いという報告があるが， 血清Lep 濃度に影響を及ぼす血中Ins数度および腎 機能障害との関連が検討された報告はない。われわ れの検討では，肝硬変患者において体脂肪率は女性 で有意に高值であるにもかかわらず，糖尿病や健常 人での報告と異なり血清 Lep 值に性差を認めなかっ た。また血清 Lep 值に影響を及ぼす因子として，多 変量解析の結果 $\Sigma$ IRI が抽出されたことから，LCの 血清 Lep 值は体脂肪率とともに、インスリン抵抗性 に影響されることが明らかとなった。【結語】肝硬 変における血清レプチン濃度は肥満のほかに, 血中 インスリン濃度，インスリン抵抗性に影響を強く受 けることが明らかとなった。

\section{PaS9-2}

肝硬変における窒素代謝と血中亜鈶濃度の関連につ いての検討

片山和宏、吉川 澄、新崎信一郎、柄川悟志、横井豊 彦、南条明子、伊藤善基、内藤雅文、石橋一伸。 （大阪厚生年金病院内科）

【目的】慢性肝疾患では病変の肝硬変への進行に伴い、 空素代謝が障害され、高アンモニア血症やフィッシャ 一比の低下などがみられるようになり、肝性脳症など の原因となっている。亜鈶は肝荿での尿素サイクルの 補醭素でもあり、肝硬変におけるアンモニアの上昇に 亜鈶の欠乏が関与していることが示されている。さら に、アンモニアは骨格筋において代謝される際、分岐 鎖アミノ酸を消費するため、高アンモニア血症はフィ ッシャー比低下の一因と考えられる。今回我々は、肝 硬変における亜鉛欠乏の実態および、これらアンモニ アやアミノ酸代謝との関連を明らかにすることを目的 とした。【方法】僈性肝疾患（慢性肝炎 40 例、肝硬変 23 例）を有する 63 症例（男性 35、女性 28）で平均年 令 64.0 才 (41-83) を対象とした。対象症例に於いて、 一般肝機能検查と血中アンモニア值、フィッシャー比、 血中亜鈶濃度を測定し、その関連を検討すると伴に、 亜鉛浱度の低下の見られる症例で、硫酸要鉛 300 $600 \mathrm{mg} / \mathrm{day}$ を投与し、血中アンモニア濃度やフィッシ ヤー比に与える影響を検討した。【成績】肝硬変では 慢性肝炎症例に比し、血中亜鉛濃度の有意の低下が見 られ(75.7 $\pm 17.5 \mu \mathrm{g} / \mathrm{dl}$ vs $87.7 \pm 10.8, \mathrm{p}=0.0013)$ 、またアン モニアの有意の上昇 $(51.2 \pm 32.8 \mu \mathrm{g} / \mathrm{dl}$ vs $34.2 \pm 10.2$, $\mathrm{p}=0.0034)$ とフィッシャー比の有意の低下 $(1.81 \pm 0.67 \mathrm{vs}$ $2.86 \pm 0.62, \mathrm{p}<0.0001)$ が見られた。また亜鉛溇度とアン

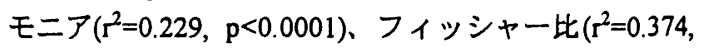
$\mathrm{p}<0.0001)$ との間には有意の相関がみられた。また硫酸 亜鈶投与の 5 症例中、 4 症例で血中亜鈶濃度の $20 \mu \mathrm{g} / \mathrm{dl}$ 以上の上昇が見られ、同症例ではアンモニア漘度の有 意の低下とフィッシャー比の上昇の傾向が見られた。

【考案】慢性肝疾患では、血中亜鉛濃度とアンモニア やフィッシャー比との間に有意の相関がみられた。肝 硬変では血中亜鉿浱度の低下が見られ、かつ重鈶を投 与することで、アンモニアやフィッシャー比の改善が 見られることより、亜鉛欠乏がこれら窒素代謝異常の 一因と考えられた。

【結語】肝硬変では亜鉛欠乏があり、これが窒素代謝 異常の一因となっている。亜鈶補充により、肝硬変の 窒素代謝異常を軽快させることが出来る。 
PaS 9-3

肝硬変における食事掫取時の門脈血行動態について の解析

一糖と半消化態栄養剤の経口負荷による比較検討一

梁町唯博 松谷正一 秋池太郎 野本裕正

中野陽子 佐藤悟郎 丸山紀史 税所宏光

(千葉大学第一内科)

【目的】肝硬変における消化管での偱環穴進状態は， 門脈理六進症の病態診断上重要である. その循環異常 については，食事との関連も指摘されているか，摄取 成分の差による反応性血行動態の違いについては明ら かにされていない，そこで，経口的な糖の負荷と，半 消化態栄養剂の投与に伴った門脈系血流の变化を検討 し，肝硬変症における食事捸取時の門脈循環動態の特 致について解析した。

【方法】肝硬変 4 例 $(58 \pm 11$ 歳) と非肝疾患 $(53 \pm 19$ 歳, 腹部手街既応例は除外） 3 例の計 7 例を対象とした。 肝硬变はC型 2 例。アルコール性 2 例で, Child A 3 列，B 1 例であり，食道胃静脈痛は 2 列に合併してみ られた。同一庭例において, 早朝空腹時にトレーラン G（G 群）およびエンシュアリキッド250m|（E 群） を別日に経口投与した．負荷前，15分およひ30分後に， 門脈本幹 (PV)，上腸間膜静脈 (SMV)，左胃静脈 (LG V), 左胃動脈（LGA）での血流を超音波ドプラ法により 測定した，PV，SIN については平均血流速度を心。 血管断面程との皘により平均血流量を算出した。 さら に，負荷前血流量と負荷後最大血流量の差を血流変化 量とした. 一方，LGV とLGA については平均血流速度 を計測し，負荷前後での最大変化を流速変化量とした. 【成綃】1. 負荷前での血流評価

肝硬変例では，PV，SMV での平均血流量および LGV

（遠肝性），LGA での血流速度は，非肝疾患例に比べ 高値を示した.

2. 負荷前後での血流変化

(1) 非肝疾患例 G 群では，PV，SMV の血流変化量は

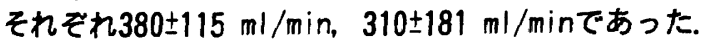
一方，E 群においてもPVおよびSWV では同様の反応性 血流増加がられ， $\mathrm{G}$ 群との有意な差は記められなか った.

（2）肝硬変例 G 群では，PV, SMV での反応性血流增 加は非肝疾患例とほぼ同様に認められた。 また，LGV は平均 $2.3 \mathrm{~cm} / \mathrm{s}$, LGA では平均 $10.3 \mathrm{~cm} / \mathrm{s}$ の流速増加が みられた. 一方E 群では, PV, SMV の血流変化量はそ れぞれ252 $\pm 140 \mathrm{ml} / \mathrm{min}, 202 \pm 45 \mathrm{ml} / \mathrm{min} と G$ 群に比べ轱 度であった. また，LGV とLGA においても，負荷後の 流速変化に乏しい傾向を示した.【䓰語】食事捸取に 伴う門脈血行動態については，肝硬変列では，非肝疾 患例と異なる反応を呈した，さらに，その血流変化は 負荷内容によっても異なり，肝硬变例では，とくに榶 質に対して強い反応性を示すことが示唆された。
PaS.9-4

高アンモニア血症の誘因となる置油〈肝硬变症例〉 馬場真二1）、池尻直幹 1)、

向坂羏太郎 2）、佐田通夫 2)

（医療法人十全会 十全病院 1）。

久留米大学医学部第二内科 2)）

【目的】アンモニアは肝硬变症における肝性脳症の重要 な一因である。血液中のアンモニアは腸内湅菌由来のみ でなく食事から得るタンパク質やクルタミン酸の影罯を 受ける。我々は、日常の食生活で使用している乵油にも アンモウニム塩が高华に含有されている事実を認め、こ れか肝硬変患者の食事療法に少なからず影霎を及ほす結 果を得たので以下報告する。

【対象及ひ方法】対象は我々の病院に入院中で、高ア ンモニア血症か 2 ヶ月以上持䊦しているアルコール性肝 硬変患者25名(HCV抗体陽性 14名、HCV抗体陰性11名)。 空腹時に濖油20mlを米饭230gと一緒に提取（以下置油 負荷)。血中アンモニア(正常值30-80 $\mu \mathrm{g} / \mathrm{d}$ ) 負荷前、 負荷後30分、60分、120分で測定。負荷前に高速液ク ロマトグラフィーによるアミノ酸分析を施行。本研究に 際し全員よりインフォームドコンセントを得た。今回の 研究に於いて全症例で肝性媨症の増悪は潖めなかった。

【成精】油負荷にて10名の患者（A群）の血中アンモ ニアの上界を辇め $(134.6 \pm 36.8 \mu \mathrm{g} / \mathrm{d}$ lvs $187.9 \pm 59.7$ $\mu \mathrm{g} / \mathrm{dl}$, mean $\pm \mathrm{SD}, \mathrm{p}<0.02$ )、残りの15名（B群）は 上界は認めなかった。アミノ酸分析では、A群はB群に

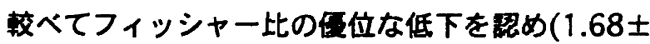

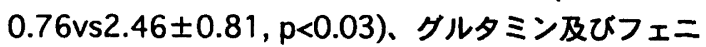
ルアラニンの優位な上异を認めた（グルタミン : 770.3 $\pm 122.2 \mathrm{nmol} / \mathrm{ml}$ vs $661.3 \pm 126.3 \mathrm{nmol} / \mathrm{ml}$, $\mathrm{p}<0.05$; フェニルアラニン : $100.4 \pm 22.5 \mathrm{nmol} / \mathrm{ml}$ vs $76.5 \pm 15.9 \mathrm{nmol} / \mathrm{ml}, \mathrm{p}<0.02)$ 。その他の生化学検 查(血小板、AST,ALT,アルブミン、総ビリルビン)は両 群間に優位差は誋められなかった。またA群の内 5 名に 対して、通常の再油に比しアンモニウム塩到が2\%以下 の”だしわりしょうゅ”を同槏に負荷したか、血中アン モニアの上昇は誰められなかった (-4.2 $218.5 \% v s 29.8 \pm 24.8 \%, p<0.01)$ 。

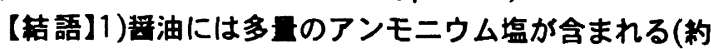
$2 \mathrm{mg} / \mathrm{ml}$ )。2)置油負荷にて血中アンモニアの優位な上 界が肝硬変患者25名の内10名で認められた。これらの 患者の負荷前の血墏のフィッシャー比は残りの15名之 比較して经位な低下が琶められた。3)肝硬変患者への "だしわりしょうゆ”負荷では血中アンモニアの上异は 認められなかった。4)フィッシャー比の低い訮硬変患者 では罯油の搑取には注意か必要である。 


\section{PaS9-5}

肝細胞窟に対する肝動脈塞栓術によるbranched chain amino acids and tyrosine ratio(BTR)への影笠 井上英和、白木克哉、伊東猛、杉本和史、山中缊成、 阪井貴久、大森茂、高瀬幸次郎、中野越 (三重大学第一内科)

【背景】肝動腺塞栓術(TAE) は肝細胞癌 (HCC)に对し て有効な治凊法の一つである。しかし、生体でのアミ ノ酸肝代謝における TAE の影䭗に関する報告は少な い。そこで我々は TAE 施行後、経過中における分岐鎖 アミノ酸(BCAA)、チロシン、そしてその二者の比であ 3 branched chain amino acids and tyrosine ratio (BTR)を経時的に测定し、TAEによるアミノ酸バラン スへの影锌を検討した。

【対象、方法】当科にて HCCに対して segmental も しくは subsegmentalにTAEを施行された 30 人を対 象とした (C 型肝硬変 29 人、アルコール性肝硬変 1 人。男 19 人、女 11 人)。いづれの症例もChildA(22 人)もしくは B(8人)であった。TAE 前、24 時間後、7 日後、14 日後の BTR、分岐鎖アミノ酸、チロシン、 アンモニア、T·Bil、prothrombin time(PT\%)、Albを 測定した。

【結果】BTR は TAE24 時間後に有意に上昇した $(\mathrm{p}<0.05)$ 。その後、徐々に TAE 前の值まで低下した $[\mathrm{TAE}$ 前 $(3.5 \pm 1.4)$ 、TAE 24 時間後 $(4.0 \pm 1.1) 、 \mathrm{TAE} 7$ 日後 $(3.5 \pm 0.9) 、 \operatorname{TAE} 14$ 日後 $(3.3 \pm 0.9)]$ 。分蚑鎖アミ ノ酸は、7 日後に若干上昇し、14 日後には低下した [TAE 前 $(406 \pm 69 \mu \mathrm{mol} / 1) 、 \mathrm{TAE} 24$ 時間後 $(433 \pm 100 \mu$ $\mathrm{mol} / \mathrm{l}) 、 \operatorname{TAE} 7$ 日後 $(457 \pm 86 \mu \mathrm{mol} / 1) 、 T A E 14$ 日後 $(408$ $\pm 69 \mu \mathrm{mol} / \mathrm{l})]$ 。チロシンは、TAE 24 時間後に有意に低 下し $(\mathrm{p}<0.05) 、 そ の$ 後上昇を見た $[\mathrm{TAE}$ 前 $(128 \pm 37 \mu$ $\mathrm{mol} / \mathrm{l}) 、 \operatorname{TAE} 24$ 時間後 $(118 \pm 32 \mu \mathrm{mol} / \mathrm{l}) 、 \operatorname{TAE} 7$ 日後 $(136 \pm 38 \mu \mathrm{mol} / \mathrm{l}) 、 \mathrm{TAE} 14$ 日後 $(129 \pm 33 \mu \mathrm{mol} / 1)]$ 。 TAE 24 時間後の BTR の上昇は、チロシンの低下によ るものであった。アンモニアの值も TAE 後低下を認め た。しかし、TAE 後の T·Bil、PT\%、Albの変化は認 めなかった。

【考察】TAE 施行にて BTR は低下せず、24時間後に むしろ上昇していた。これは、チロシンが TAE 後に低 下した事に由来するものと考えられた。その原因は不 明であるか、TAEによる肝虚血状態が、チロシンの代 謝に関与している可能性が推測された。

【結語】以上の結果より、segmental な TAE は ChildA もしくはBの所硬変において、アミノ酸代謝（特にチ ロシン)に影䈉を及ほすものの、BTR を覀化させるこ とは少ないと考えられた。
PaS 9-6

潜在性肝性脳症における脳内物質代謝異常に対する分岐鎖 アミノ酸輸液の影垔

池田亘政、加藤章信、藤島裕耕、岩井正勝、遠藤龍人 鈴木一幸

(岩手医科大学第一内科)

【目的】肝硬变では磁気共鳴分析法(MRS)の検討により脳内 myo-inositol (mI)の減少とglutamine (Gln)の增加があり、これ らの脳内物質のインバランスが肝性昏睡の成因として注目さ れている。肝硬変に分岐鎖了ミノ酸(BCAA)輸液を行い、脳 内物質バランスが变化する可能性を報告したが(第 35 回日 本肝臟学会総会)、潜在性肝性脱症(SHE)の病態とBCAA輸液 投与との関係は明かではない。そこで、今回肝硬変をSHEの 有無より分け、BCAA輸液前後でMRSを施行し、mI と Glnな らびに血液アンモニア $\left(\mathrm{B}-\mathrm{NH}_{3}\right)$ との関連より検討した。

【対象と方法】SHEを有する肝硬変10例 (男性7例、女性3例、 平均年齡57才、成因 : HBV2例、HCV6例、アルコール性1例、 不明1例)。非SHEの肝硬変17例 (男性12例、女性5例、平均年 齢55才、成因: HBV3例、HCV8例、アルコール性5例、PBC1

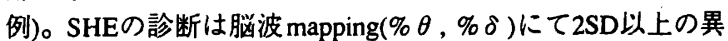
常を認めた例とした。'H(proton)-MRS (GE社製SIGNA1.Stesla) は後頭葉内側灰白質に関心領域を設定しcreatineの信号强度で 補正定量化し\%表示した。またSHE5例と非SHE(5例)にBCAA 輸夜を $(0.5 \mathrm{ml} / \mathrm{kg})$ を投与し $\mathrm{mI} 、 \mathrm{G} \ln$ の変化を検討した。

[成䋘] (1)ml，GinとSHEとの関連：SHE例でのGln信号強度 $(30 \pm 10 \%)$ は非SHE例 $(30 \pm 11)$ と差はないが、SHE例のml信 号強度 $(26 \pm 13 \%$ ) は非SHE例 $(32 \pm 14)$ に比し有意 $(\mathrm{p}<0.05)$ に 低値を示した。さらに対象全例でB-NH3 との相関をとるとmI は有意( $(\mathrm{p}<0.05)$ の負の相関を、GIn仙有意 $(\mathrm{p}<0.05)$ の正の相関 を示したが、潜在性の有無によるB-NH 3 の差異は認められな かった。(2)BCAA输液のMRS信号強度に及ぽす奻果：SHE ではm[は変化は無く、GIn住上昇（前値に対す万增加率23.2 土3.9\%)したが、非SHE例ではmIが上昇 $(22.8 \pm 4.6 \%) し G \ln$ は

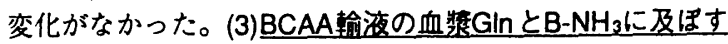
効果：B-NH3 はSHE、非SHEとも輸液後2時間では前値に比 し上昇(各々 $52.3 \pm 17.9 \%, 72.4 \pm 74.0 \%$ )した。一方、輸液後

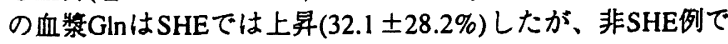
は変化少なく $(9.0 \pm 14.3 \%)$ 、脳内での $\ln$ の変動と同様の傾 向を示した。

【考察】脳内物質動態とB-NH3 とは相関するが、one pointの B-NH3 3 は必ずしもSHEの病態を反映しない。BCAAを含むア ミノ酸輸液によりSHEでは脳内、末梢ともGinが上昇し、非 SHE例では変化がみられなかった。このことから、SHEでは 非SHE例に比LGIn形成を介したアンモニア代辚機能が障害 されている可能性がある。一方、非SHE例ではGInは変化な く、mIの上昇がみられ、脳内物犋のインバランスの改善傾向 がみられるが、その機序についてはさらに検討を要する。

【結論】肝硬变での脳内物質代謝異常はBCAA輸液療法によ り改善する可能性があるが、SHEと非SHEでは、BCAA輸液 時の脳内のアンモニア処理能が異なる可能性が示唆された。 
PaS9-7

分岐鎖アミノ酸（BCAA）は mTOR 情報伝達系を介して ラット初代肝細胞のアルブミン合成を促進する

伊地知千織、辻尚志、江藤讓

（味の素（株）医薬研究所）

\section{「目的」}

経口 BCAA 製剤は肝硬変患者の血獎フィッシャ一比 (BCAA/AAA)を増加させ、低下した血清アルブミン量を 改善する。ラット初代肝細胞を用いて正常なフィッシ ヤー比がアルブミン合成を促進することが示されてい るが *、その分子レベルの作用機構は不明である。

最近、アミノ酸による蛋白質合成開始のシグナルが mTOR (mammalian Target of Rapamycin)を介して伝達 されることが報告された。我々はラット初代肝細胞を 用い、BCAA のアルブミン合成に及ぼす作用機檕を mTOR 情報伝達系に注目して解析した。

「方法」

雄Wistar ラット 6 週齢より肝実質細胞を分離し、 $1 \%$ 牛胎児血清を含む RPMI 培地に㦟濁して $1 \times 10^{5}$ 個/ $\mathrm{cm}^{2}$ になるようにコラーゲンコートプレートに播種 した。アミノ酸および血清を含まない RPMI 培地で $37^{\circ} \mathrm{C} 、$ $5 \% \mathrm{CO}_{2}$ 存在下で 1 時間培養した後、各種アミノ酸、畂OR 阻害剂ラパマイシンを添加して 6 時間培羕した。培養 上清中のアルブミン量を抗アルブミン抗体とユーロピ ウムラベルしたアルブミンを用いて定量した。アルブ ミン mRNA 量を定量 RT-PCR 法で、細胞数を検鏡計測お よびMTT活性を指標に測定した。

「結果と考察」

（1）BCAA は 0.1-2mM の生理的洤度範囲で鋠度依存的 にアルブミン合成を最大 1.7 倍に促進した。

（2）BCAA の中ではロイシンが主たる活性を示した。 BCAA を混合する効果も見出された。BCAA 以外のアミノ 酸 $(2 \mathrm{mM})$ には活性が認められなかった。

(3) ロイシンのアルブミン合成促進活性は mTOR 阻害 剤ラパマイシンで約 $50 \% に$ 抑制された。

（4）ロイシンおよびラパマイシンの添加による細胞 数（MTT 活性）、アルブミン mRNA 量に変化はみられな かった。

「結語」

ラット初代肝細胞において、BCAA（特にロイシン） は生理的洤度で mTOR 情報伝達系を介してアルブミン 合成を促進することが示唆された。

\# Okuno, M., et.al., (1995) Biochem. Biophys. Res. Commun., Vol.214 (3) p 1045-1050
PaS9-8

障害肝におけるパリン代謝系醭素 (crotonase、HIB-CoA hydrolase)の活性低下と発現の変化

石榑 清 1)、下村良治 2)、村上太郎 2)、金子暂也 1)、 竹田 伸 1)、井上総一郎 1)、野本周嗣 1)、中尾昭公 1) (1)名古屋大学第二外科、2)名古屋工業大学保健科)

【目的】生体内におけるバリン代謝過程において産生され る methacryryl-CoA は極めて毒性が高い中間代謝産物とし て知られているが、肝細胞内では methacryryi-CoA hydratase( 以下 crotonase) と 3-hydroxyisobutyryl-CoA hydrolase(以下 HIB-CoA hydrolase)により速やかに分解され る。今回、背景肝の障害程度によりこれらの2つの醳素活 性と mRNA 発現の変化を検討した。【対象、方法】肝切除 術時に探取されたヒト正常肝 $(n=11)$ 、慢性肝炎 $(n=11)$ 、肝 硬変 $(n=8)$ および肝細胞癌 $(n=12)$ の 4 群において crotonase 活性、HIB-CoA hydrolase 活性を光学的測定により定量し た。また肝ミトコンドリアの標識酲素として citrate synthase 活性も同様の方法にて定量した。mRNA 発現の定量はRTPCR 法にて行い、 $\beta$ actin を内部標識マーカーとした。【結 果】crotonase 活性は、正常肝 $12039 \pm 704 \mathrm{mU} / \mathrm{g}$ 、慢性肝炎 $10752 \pm 767 \mathrm{mU} / \mathrm{g}$ 、肝硬変 $8564 \pm 600 \mathrm{mU} / \mathrm{g}$ 、肝細胞癌 6624 $\pm 779 \mathrm{mU} / \mathrm{g}$ と肝障害の程度が進行するにつれ徐々に低下し た。HIB-CoA hydrolase 活性も同様に、正常肝 $9097 \pm$ $603 \mathrm{mU} / \mathrm{g}$ 、慢性肝资 $8811 \pm 761 \mathrm{mU} / \mathrm{g}$ 、肝硬変 $7025 \pm 530 \mathrm{mU} / \mathrm{g}$ 、 肝細胞癌 $6602 \pm 601 \mathrm{mU} / \mathrm{g}$ と肝障害の程度が進行するにつ 机徐々に低下した。肝ミトコンドリア密度を反映する citrate synthase 活性は各群で有意差を認めなかった。 crotonase の mRNA は正常肝を1 とすると慢性肝资 1.31、

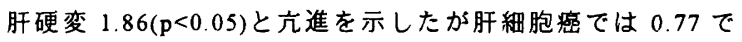
あった。HIB-CoA の mRNAも同様に正常肝を 1 として慢 性肝炎 1.38、肝硬変 $2.29(\mathrm{p}<0.05)$ と六進を示し肝細胞癌は 1.37 であった。一方内部標識マーカーとした $\beta$ actin の mRNA は正常肝を1として慢性肝炎 1.19、肝硬変 1.17 で 有意な差がなく肝細胞癌では 1.69 と高値であった。

【結語】正常肝から慢性肝炎、肝硬変へと肝障害が進行す るに伴って crotonase および HIB-CoA hydrolase の mRNA は高值を呈したか、醳素活性レベルでは逆に低下していた。 この結果 methacryryl-CoA の分解遅延をきたし肝緗胞障害 の進行と関連する可能性が示唆された。肝細胞癌では mRNA、酻素活性のいずれも低値を示しており細胞分化の 程度との関連が推測された。 